\title{
Public Displays of Student Learning: The Role of Literary Societies in Early Iowa Higher Education
}

\author{
Michael S. HeVEL
}

AT SIX O'CLOCK in the evening on June 13, 1911, student and alumni members of the Zetagathian Literary Society at the State University of Iowa (SUI) gathered in the banquet hall of the Burkley Imperial Hotel in Iowa City to celebrate the organization's fiftieth anniversary. The 127 "Zets" in attendance, representing over 10 percent of all the men that the society had initiated since its inception, sat next to former classmates at tables arranged into the letters $Z$ and I. Having paid one dollar for their dinner, many members wore a pennant-shaped red leather badge inscribed in gold lettering with "Zet Semi-Centennial, 1861-1911" that they had received the previous morning at registration. There, in the Drawing Room of the Hall of Liberal Arts (today's Schaeffer Hall), alumni met the current student members of the literary society and perused the old society records on display. Later that afternoon the reunion attendees gathered for a photograph in front of the society's first meeting place, the

\footnotetext{
A State Historical Society of Iowa research grant funded this study. The archivists at Cornell College, the University of Northern Iowa, and the University of Iowa - especially Kathy Hodson, Gerald Peterson, and Jennifer Rouse proved patient and helpful with my first research project. Professors Linda K. Kerber and Christine A. Ogren at the University of Iowa provided insightful comments on earlier drafts. Suggestions from Annals of Iowa editor Marvin Bergman and the anonymous reviewers greatly improved the final draft. Lane Schmidt digitally enhanced the images.
}

THE ANNALS OF IOWA 70 (Winter 2011). (C) The State Historical Society of Iowa, 2011. 
Old Capitol, the state's first capitol building and SUI's first permanent campus building. As the banquet ended, the Zets left the hotel for the Iowa City Commercial Club, where a typical society meeting followed. The society elected three of its banquet guests, including SUI President George MacLean, as honorary members. Then the Zets began "motions of various sorts [that] brought forth vigorous discussions [and] fighting over again the old time parliamentary battles of yore." After the spirited discussion, about 30 Zets spoke on the history of the society and hopes for its future, with some "note of sadness or regret at the changed position of literary societies in the University."

The Zets had many reasons to celebrate. Their society, the oldest student organization at SUI, had made significant contributions to the university. But the Zets did not make such contributions alone, either at SUI specifically or within Iowa higher education generally. Members of SUI's other literary societies joined the Zets in providing important learning experiences for students. Although attending very different institutions than SUI, literary society members at Cornell College in Mount Vernon and at the Iowa State Normal School in Cedar Falls provided similar opportunities for students and made similar contributions to their respective campuses. Through their programs, society members demonstrated their educational gains, improved their speaking abilities, and practiced the cultural arts. In addition to these programs, society members were instrumental in creating features of campus life that endure to the present. Indeed, literary societies played a formidable if largely forgotten role in early Iowa higher education, providing opportunities for students to display publicly, in a variety of changing formats over the years, their higher learning.

Although the contributions of student literary societies to higher education in Iowa have generally been forgotten, historians have argued the educational significance of literary societies across different institutional types and different time periods. Historians writing in the 1960s and 1970s primarily analyzed white men's experiences at eastern colleges before the Civil War. First established at Yale, Harvard, and Princeton in the mid-

1. Theodore A. Wanerus, History of the Zetagathian Society of the State University of Iowa (Iowa City, 1911), 199-206. 
eighteenth century, a tradition of two rival literary societies quickly spread to other campuses. Historians best remember literary societies for their debates in which college men engaged political issues and for their establishment of private libraries. The most prevalent theme running through early accounts of literary societies is their curricular significance during a period known for a curriculum that provided college men neither intellectual encouragement nor practical relevance. ${ }^{2}$ More recently, historians have demonstrated that literary societies were an important feature of the higher education of women students at academies and seminaries beginning in the late eighteenth century, at land-grant colleges in the 1870s and 1880s, and at state normal schools until the early twentieth century. ${ }^{3}$ Despite the attention given to literary societies, historians seldom consider these organizations across different institutional types. ${ }^{4}$

2. The notable and recent exception to "forgotten" Iowa literary societies is Andrea G. Radke-Moss, Bright Epoch: Women and Coeducation in the American West (Lincoln, NE, 2008), chap. 3, who considers how women experienced coeducation at four land-grant colleges, including Iowa Agricultural College (today's Iowa State University). Radke-Moss argues that literary societies provided a space where women students negotiated the tension between separation and inclusion inherent in early coeducational institutions. On the development of men's literary societies and their curricular significance at eastern colleges, see Frederick Rudolph, The American College and University: A History (New York, 1962), 136-44; James McLachlan, "The Choice of Hercules: American Student Societies in the Early 19th Century," in The University in Society: Europe, Scotland, and the United States from the 16th to the 20th Century, ed. Lawrence Stone (Princeton, NJ, 1974), 440-94; Thomas S. Harding, College Literary Societies: Their Contribution to Higher Education in the United States, 1815-1876 (New York, 1971); Lowell Simpson, "The Development and Scope of Undergraduate Literary Society Libraries at Columbia, Dartmouth, Princeton, and Yale, 1783-1830," Journal of Library History 12 (1977), 209-21; and Frederick Rudolph, Curriculum: A History of the American Undergraduate Course of Study Since 1636 (San Francisco, 1977), 95-98. For the brief resurgence of interest in literary societies at these institutions after the Civil War, see Bruce Leslie, Gentlemen and Scholars: Colleges and Community in the "Age of the University" (University Park, PA, 1992), 196-98.

3. See Mary Kelley, Learning to Stand and Speak: Women, Education, and Public Life in America's Republic (Chapel Hill, NC, 2006), 117-32; Radke-Moss, Bright Epoch, chap. 3; and Christine A. Ogren, The American State Normal School: "An Instrument of Great Good" (New York, 2005), 108-119.

4. The closest exploration of literary societies across institutional type occurs in Kolan Thomas Morelock, Taking the Town: Collegiate Community Culture in the Bluegrass, 1880-1917 (Lexington, KY, 2008), chaps. 3 and 4. Morelock explores the developments of literary societies during the evolution of Transylvania 
ONE OF FOUR STATES admitted to the Union during the 1840s, Iowa achieved statehood in 1846, a year after Florida and Texas and two years before Wisconsin. Iowa's population grew dramatically: four years after statehood, fewer than 200,000 people lived in Iowa, ranking the state as one of the least populous, but almost 1.2 million people lived in Iowa by 1870. Although Iowa's population was exploding, it was home to few racial minorities. The Census Bureau counted fewer than 6,000 African Americans and just three Chinese American residents in $1870 .{ }^{5}$

To accommodate their state's growing population, Iowans began establishing institutions of higher education. Coeducation was a marked feature of many of the new institutions. In 1853 Methodist leaders formed the Iowa Conference Male and Female Seminary, which consisted of a primary and preparatory school, on a hill outside Mount Vernon. The board of trustees shortened the institution's name to Iowa Conference Seminary the following year, before adding a collegiate department and changing its name to Cornell College in 1855. Legislators created the State University of Iowa (today's University of Iowa) in Iowa City by statute in 1847, although the institution did not hold classes until 1856. That September more than one hundred students enrolled in its preparatory and normal departments, while only 15 men and 4 women studied at the college level. The next year the collegiate department was suspended and did not reopen until 1860. Iowa State Normal School (ISNS) - later known as Iowa State Teachers College and eventually the University of Northern Iowa - opened outside of Cedar Falls in 1876. Four faculty members taught 27 students on the institution's inaugural day, but by the end of the first term the student body had increased to $88 .^{6}$

University and the prominent role of literary societies of several colleges in Lexington's public life in the last decade of the nineteenth century.

5. Ninth Census: The Statistics of the Population of the United States, vol. 1 (Washington, DC, 1872), ix-xvii, 3, 27-29, 131-42.

6. William C. Heywood, Cornell College: A Sesquicentennial History, 1853-2003, (Cedar Rapids, 2004), 3-5; J. L. Pickard, "Historical Sketch of the State University of Iowa," Annals of Iowa 4 (1899), 7, 31, 33; William C. Lang, A Century of Leadership and Service: Iowa State Normal School 1876-1909, Iowa State Teachers College 1909-1961, State College of Iowa 1961-1967, University of Northern Iowa 1967- (Cedar Falls, 1990), 1. 
Male students established literary societies during each of the three institutions' first year. Four days after the Iowa Conference Male and Female Seminary moved from its temporary location in Mount Vernon's Methodist church into the newly finished building in November 1853, 22 men founded the Amphicyton Literary Society. Men at Iowa State Normal School were nearly as eager to launch a literary society. After that institution's first term, ten men organized the Philomathean Society in January 1877. The first men at SUI, preoccupied with the looming Civil War when the collegiate department reopened, often neglected their studies in favor of practicing military drills. But that did not prevent 13 men from founding the Zetagathian Society in April 1861. The new "Zets" stopped their military drills long enough to gather in a dimly lit room in the northwest corner of the Old Capitol to debate whether "Christopher Columbus deserves more honor for discovering America than George Washington for saving it." ${ }^{7}$ Rival men's societies, similar to those typical at eastern colleges, developed at all three institutions within a decade of their openings. ${ }^{8}$

But before a rival men's society developed on any of these three campuses, female students established their own literary societies. Three months after men formed the first literary society at ISNS, seven women created the appropriately named Alpha Society. Two additional women's societies developed before another men's society formed at ISNS. Early women students at SUI started two literary societies: 22 women founded the Erodelphian Literary Society in October 1862, and women students, primarily from the normal department, established the Hesperian Literary Society in the spring of $1863 .{ }^{9}$ The Hesperians en-

7. Heywood, Cornell College, 21; Lang, A Century of Leadership, 189; Wanerus, Zetagathian Society, 5-10.

8. Heywood, Cornell College, 56; S. B. Montgomery and G. H. Kerr, "History of the Adelphian Society," The Sibylline, Adelphian Literary Society Papers, Cornell College Archives, Russell D. Cole Library, Cornell College, Mount Vernon (hereafter cited as CCA); Clifford Powell, L. O. Smith, and I. N. Brant, History and Alumni Register of Irving Institute of the State University of Iowa (Iowa City, 1908), 6-7; Lang, A Century of Leadership, 189.

9. Most sources agree that women students founded the Hesperian Society in the spring of 1863 , but the Hesperians themselves occasionally disputed this. In the second yearbook published at the university, the Hesperians wrote of 
countered greater membership challenges because the normal department's curriculum was shorter than the collegiate department's requirements and because the students in that department were more likely to accept teaching positions during the academic year. Women at Cornell College waited the longest after their institution's opening to form a literary society, but they still formed the oldest women's society among the institutions. In December 1857 Cornell College women established the Philomathean Literary Society, nearly 20 years before men at the state normal school selected the same name. ${ }^{10}$

As time passed and the institutions matured, students established more literary societies, breaking the national trend of having only two rival societies on a campus. ${ }^{11}$ In 1895 several ISNS Philomathean alumni who continued their education at SUI decided to organize another men's literary society, naming the new society after their old one. Writing back to the Philos in Cedar Falls, these students asserted that their new society was "a branch of the old 'Philo' society at I.S.N.S." Women formed long-lasting literary societies at each campus during the early twentieth century, including the Aonian Literary Society at Cornell, the Octave Thanet and Hamlin Garland literary societies at SUI, and the Chrestomathian Literary Society at ISNS. The Octave Thanet and Hamlin Garland societies at SUI named themselves after authors who had lived in and written about Iowa, and those authors visited the societies several times. Although most literary societies were active for decades, on each campus

their founding: "Hesperia's early record, more priceless than Sibylline's books, were, like them, destroyed ere mortals knew their potency. Hence, it must ever remain a question which puzzles the profoundest thinkers, whether the Hesperian was the first or second young woman's literary society to be established in the State University of Iowa." "Hesperian Literary Society," The Hawkeye: Junior Annual of the Class of '93 (Iowa City, 1892), 99.

10. Lang, A Century of Leadership, 66, 189; Helen E. Lavender, "A History of the Erodelphian and Hesperian Societies of the State University of Iowa with a Brief Résumé of the Octave Thanet, Whitby, Athena, and Hamlin Garland Societies" (master's thesis, State University of Iowa, 1937), 1-4; Heywood, Cornell College, 56.

11. For an interesting account of students' unsuccessful efforts to form a third literary society at Princeton, see Steven J. Novak, The Rights of Youth: American Colleges and Student Revolt, 1798-1815 (Cambridge, MA, 1977), 36-37. 
TABLE

STUDENT LITERARY SOCIETIES BY INSTITUTION

\section{Cornell College}

\begin{tabular}{llll}
\hline Men's Societies & Years Active & Women's Societies & Years Active \\
\hline Amphicyton & $1853-1928$ & Philomathean & $1857-1928$ \\
Adelphian & $1859-1928$ & Aesthesian & $1872-1928$ \\
Star & $1876-1928$ & Alethean & $1888-1928$ \\
Miltonian & $1888-1928$ & Aonian & $1902-1928$ \\
Parmenian & $1916-1928$ & Promethian & $1916-1928$ \\
& & Thalian & $1916-1928$
\end{tabular}

Iowa State Normal School (University of Northern Iowa)

\begin{tabular}{llll}
\hline Men's Societies & Years Active & Women's Societies & Years Active \\
\hline Philomathean & $1877-1929$ & Alpha & $1877-1935$ \\
Aristotelian & $1886-1929$ & Shakespearean Circle & $1884-1937$ \\
Orio & $1893-1922$ & Cliosophic & $1886-1932$ \\
Men's Forum & $1929-1932$ & Neotrophian & $1891-1934$ \\
& & Zetaletheans & $1893-1935$ \\
& & Margaret Fuller Ossoli & $1897-1930$ \\
& & Chrestomathian & $1902-1934$ \\
& & Eulalian & $1908-1934$ \\
& & Delphian & $1908-1935$ \\
& & Homerian & $1913-1930$ \\
& & Irving & $1913-1933$
\end{tabular}

State University of Iowa (University of Iowa)

\begin{tabular}{llll}
\hline Men's Societies & Years Active & Women's Societies & Years Active \\
\hline Zetagathian & $1861-1933$ & Erodelphian & $1862-1933$ \\
Ciceronian & $1863-1864$ & Hesperian & $1863-1933$ \\
Irving Institute & $1864-1929$ & Octave Thanet & $1900-1933$ \\
Philomathean & $1895-1928$ & Whitby & $1913-1928$ \\
Rhoterian & $1922-1928$ & Athena & $1916-1933$ \\
& & Hamlin Garland & $1920-1934$
\end{tabular}

Note: Founding dates are easier to identify than dating societies' demise. Many ending dates are estimated by the last year the organization appeared in a campus yearbook. All literary societies at Cornell College ceased to exist when the faculty permitted students to form social groups, but for many organizations it is unclear if they stopped functioning prior to 1928. At ISNS in 1929, the Philomatheans and Aristotelians combined their membership to establish the Men's Forum. 
several literary societies formed in the twentieth century that had comparatively brief existences (see table). ${ }^{12}$

Open to most students, literary societies were more egalitarian than many later features of campus life, such as fraternities and sororities and intercollegiate athletics. Despite this relative openness, these organizations, like the institutions to which they belonged, were most accessible to white students. Surviving evidence suggests that African American students were neither formally excluded from SUI's literary societies nor did they ever join one. With assistance from local residents, African American women at SUI organized the Mary Church Terrell Club in 1913, and African American men created the DuBois Club. Although these organizations shared some common features with literary societies, much of these students' energies necessarily focused on addressing the racial inequities found on campus and in the community. Cornell College barred African Americans from enrolling before reversing that decision in 1870. The Amphicytons welcomed the college's first black student as a member; he remained active in the society for two terms until he withdrew from the college. African Americans never attended ISNS in large numbers while literary societies were active, but literary society members occasionally made "Negro life in the South" the focus of their society programs. ${ }^{13}$

Academic leaders at each institution publicly demonstrated the importance of literary societies in three significant ways. First, faculty members helped students create literary societies. At their first meeting at SUI, the founding Erodelphians asked Professor Oliver Spencer, then acting president of the infant university, to write the society's constitution. At ISNS, Miss

12. "To our Brother 'Philos' of the I.S.N.S.," The Normal Eyte (Cedar Falls), 12/14/ 1895, 114; "Historical Mention of the Members of the Philomathean Forensics Society," Philomathean Forensics Society Papers, University Archives, University of Northern Iowa, Cedar Falls; Lang, A Century of Leadership, 189; Treasure Book of the Rhoterian Literary Society, 1923-24, Rhoterian Literary Society Papers, University Archives, University of Iowa Libraries, Iowa City (hereafter cited as UIA); "Men's Forum," College Eye (Cedar Falls), 9/19/1929, 5.

13. Richard Melvin Breaux, "'We must fight race prejudice even more vigorously in the North': Black Higher Education in America's Heartland, 1900-1940" (Ph.D. diss., University of Iowa, 2003), 163-74; Heywood, Cornell College, 63; "Society Notes," Normal Eyte, 2/13/1897; "Philo Public," Normal Eyte, 4/8/1899; "Orio" and "Neo," Normal Eyte, 10/3/1903; "Alpha," Normal Eyte, 11/14/1903. 
Webster, an instructor, encouraged the first women students to establish a literary society. She "christened" it Alpha, not only because it was the institution's first women's society but also because it was the name of the society she had belonged to as a normal school student in New York. Later, faculty members continued to be catalysts in forming literary societies at ISNS. Marion McFarland, an instructor of applied English, helped organize the institution's fourth women's society in 1891. A year later, the faculty further empowered McFarland, instructing her to organize temporary societies as needed. Cornell College faculty members were especially instrumental in founding societies. Dr. Samuel Fellows, the principal of the seminary, and Professor David Wheeler were both founding members of the Amphicyton Literary Society. Individual faculty members helped establish two more men's societies in the 1870s. The college's preceptress, Miss Susan Hale, organized the first women's society. Despite her influential role in founding the society, one early student recalled, "Most of the girls were decidedly opposed to having the lady teachers present as active members [of] the soc[iety]; the teachers, fully appreciating this feeling silently absented themselves from the soc[iety] meetings after meeting with us twice." While students appreciated (and needed) faculty support for their organizations, they wanted to control the societies themselves. ${ }^{14}$

At different times and to varying degrees, faculty members also awarded academic credit to students for participating in literary societies. From 1863 to 1873 , literary society members at SUI received partial credit for "rhetorical exercises." Ten years after students first established literary societies at ISNS, the "overburdened" faculty members allowed society work to meet a similar curricular requirement. Under this arrangement, members performed an original exercise once a month during a literary society meeting. Faculty members awarded academic credit

14. Lavender, "Erodelphian and Hesperian," 1; Lang, A Century of Leadership, 66, 189-90; Heywood, Cornell College, 56-57; James "Dietrich" Scollay, "The Miltonian Alumni Register, 1871-1981," 4, Miltonian Literary Society Papers, CCA; "Star Society History," The Sibylline, vol. 1, Star Literary Society Papers, CCA; Amanda Plaskett Smead, "After Reading the Sibylline (Vol. 1) - 1888," 2-3, Philomathean Literary Society Papers, CCA. 
after society officers reported which students fulfilled the requirements. Students at ISNS who chose not to join a literary society had to meet weekly with faculty members to fulfill the same requirement. Literary society men at Cornell College received three hours of academic credit for participating in debates arranged by the Debating League. To receive credit, men had to comply with faculty regulations that required students to enroll in one fewer class than normal, be in good standing with the faculty, take seven public speaking lessons, and receive the approval of his class officer. ${ }^{15}$

Finally, at young campuses with few buildings, institutional presidents and governing boards demonstrated the importance of early literary societies by providing rooms for them. At Cornell College, Amphicyton members did not wait until doors, windows, or even floors were installed in the campus's second building before finding a permanent home for their organization. On a "cold bleak night" in November 1857, the young men climbed a ladder to the third and highest story of the unfinished College Hall. From that high and risky perch, members teetered across wooden support beams until they reached a specific location to claim the future home of their society. The Philomathean women, waiting until stairs and floors were built, selected a room across the hall on the same floor. The two earliest literary societies at ISNS also secured society halls. The attic space above the chapel in South Hall (later named Gilchrist Hall) was divided in two, providing each society with a room. At SUI, South Hall became the home of the first four literary societies in 1869. Originally intended to serve as a dormitory, the three-story "plain brick structure" quickly became classroom space for the growing university, but SUI officials apportioned the third floor among the four literary societies and the Board of Regents provided limited funds to "finish and furnish" the rooms. ${ }^{16}$

15. Lavender, "Erodelphian and Hesperian Societies," 16; Lang, A Century of Leaderhip, 189-91; "Constitution of the Debating League of Cornell College," Debating League Papers, CCA.

16. Heywood, Cornell College, 13; Rev. John Onesimus Foster, "Early Recollections of Cornell College, Mount Vernon, Iowa" (1916), 11, CCA; Montgomery and Kerr, "History of the Adelphian Society"; "Old Literary Societies Stole Social Stage," College Eye, 10/20/1939, 7; Wanerus, Zetagathian Society, 248; Pickard, "Historical Sketch," 25-26; W. M. J. Haddock to Iowa State Board of 
Societies that formed later often struggled to find space on campus. In its first year at SUI, the Philomathean Literary Society met in an attic room in the Dental Building. The men did not find that arrangement agreeable, arguing that the room "was entirely unsatisfactory and on account of its location there was much difficulty in getting visitors to attend the meetings and programs." The society soon moved to the history room in South Hall for its meetings. Following a fire that destroyed South Hall in 1901, the society temporarily met in the Philosophy Building. Finally, in the fall of 1902 the university offered the society the southwest room of Close Hall. There is no record of literary societies established after 1900 at SUI ever securing permanent space. The societies that formed after the Philomathean and Alpha at ISNS did not receive permanent space until 1902, when the completion of the Auditorium provided five additional rooms for the societies. The Miltonians at Cornell purchased a half-interest from the Philomatheans to share their hall on the third floor of College Hall, but their historian cautioned, "Though the Milts shared this hall with the Philomathean women, it appears they shared little else, including a fondness for one another." ${ }^{17}$ New literary society members' efforts to secure a society hall and older societies' members' displeasure with sharing their halls with upstarts suggest that these students recognized the prestige permanent homes in campus buildings brought to their organizations.

Established during a period to which some historians have dated the demise of these organizations, ${ }^{18}$ literary societies enjoyed a long life at Cornell College, Iowa State Normal School, and the State University of Iowa. At these institutions, literary societies remained active on campus until the 1920s and 1930s,

Regents, "Mem. of Aid Given the Societies for Board," 5/24/1889, University Manuscript File Collection, UIA.

17. Lang, A Century of Service, 191; "Historical Mention of the Members of the Philomathean Forensics Society," 3, 5, Philomathean Forensics Society Papers, UIA; Lavender, "Erodelphian and Hesperian Societies," 121-26; Scollay, "Miltonian Alumni Register," 5; "Bill of Sale," 3/10/ 1902, Amphicyton Literary Society Papers, CCA.

18. See Helen Lefkowitz Horowitz, Campus Life: Undergraduate Cultures from the End of the Eighteenth Century to the Present (Chicago, 1987), 28; Rudolph, The American College, 145; and Harding, College Literary Societies, 297. 


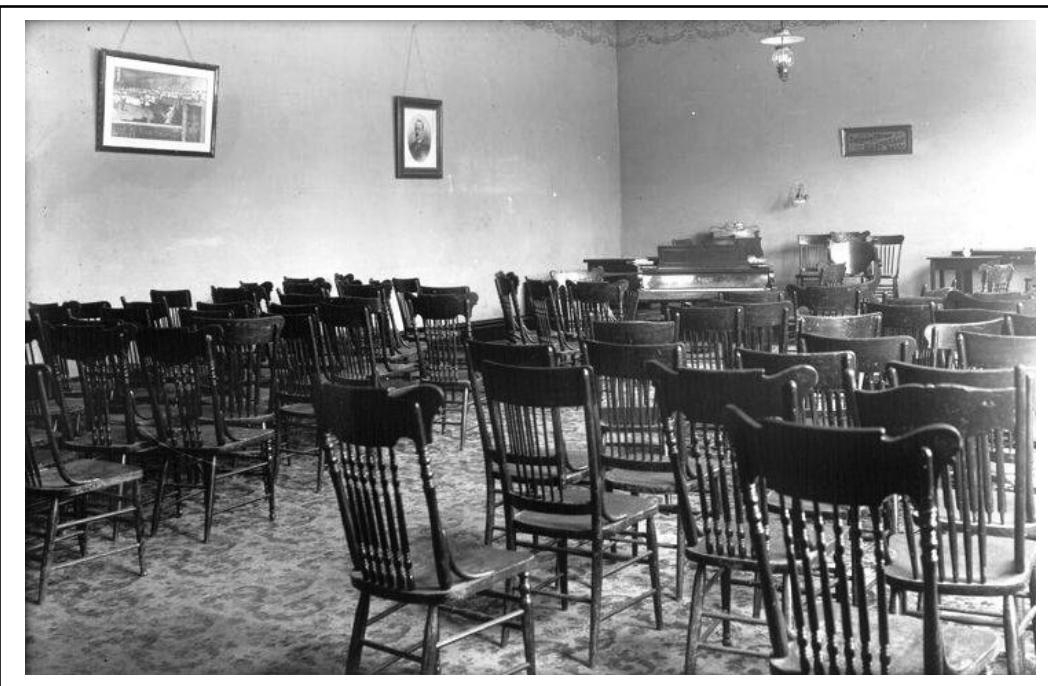

The Zetagathian room inside Close Hall at SUI in 1910, several years after a fire destroyed the original room in South Hall. The spindle-back chairs face the front of the room, where the audience would find a piano, the president's chair, and an elevated platform for speakers. From Samuel Calvin Collection of Photographs, Special Collections and University Archives, University of Iowa Libraries, available online at Iowa Digital Library (www.digital.lib.uiowa.edu).

when an expanded curriculum and extracurriculum supplanted the purposes of the institutions' first student organizations. In the meantime, the societies' programs and contributions to campus life gave members opportunities to publicly display their higher learning.

AS THEIR MAIN ACTIVITY at all three institutions, literary societies planned programs that enabled members to demonstrate and refine their public speaking skills. Societies presented such programs regularly, sometimes weekly. Typically held on Friday or Saturday, men's and women's programs usually occurred on different days, although the societies occasionally combined efforts to present a joint program. Men's and women's societies often paired off to become "brother" and "sister" societies. Members of the brother society attended their sister society's 
programs in large numbers, and the women returned the favor for men's programs. Literary societies often opened their programs to the public and advertised their upcoming programs. In an era before radio or movies, society programs provided entertainment for students and the broader community.

Debates always served as the central feature of men's literary societies; women's programs often included debates but emphasized a greater variety of forensic activities. The first constitution of the Philomathean men at ISNS mentioned several activities to be included in their "regular exercises" but listed "debates" first. The first interaction between the Zets and the younger Irving Institute was an intersociety debate in June 1865. The Zets argued in favor of capital punishment, winning the debate described as "one of the most important events in their history." At the first meeting of Cornell College's Philomathean Society, the institution's two female instructors read papers they had written. At SUI, Erodelphians initially alternated the focus of their programs between debates and members reading compositions. Over the course of the 1870-71 academic year, Erodelphian programs included 87 essays, 29 declamations, 24 orations, and 12 debates. The early Alpha programs at ISNS closely mirrored the men's programs, but the women regularly included a summary of current events and a biography of an influential figure. ${ }^{20}$

Literary societies advertised their programs with posters placed in prominent locations on campus. Surviving posters of SUI's Zetagathian men and Hesperian women illustrate the differences between men's and women's literary societies. In their debates, the Zetagathians typically argued over international, national, and state politics. In the spring of 1898 the Zets debated government-owned railroads, immigration, the Electoral College,

19. Students' Offering (Cedar Falls), 2/1/1879; Wanerus, Zetagathian Society, 52.

20. "Sixth Anniversary of the Amphicyton Society of Cornell College, Mt. Vernon" (1859), Amphicyton Society Papers, CCA; Montgomery and Kerr, "History of the Adelphian Society"; Lang, A Century of Leadership, 65, 66; Wanerus, Zetagathian Society, 48, 38-39; Smead, "After Reading the Sibylline," 2-3; Lavender, "Erodelphian and Hesperian Societies," 24, 66. The student historians of the Adelphian Literary Society at Cornell College wrote in 1888, "Formerly the programs were chiefly in line of debate, now the exercises are varied and more formal." "Adelphian Society History," The Sibylline, vol. 1, Adelphian Literary Society Papers, CCA. 


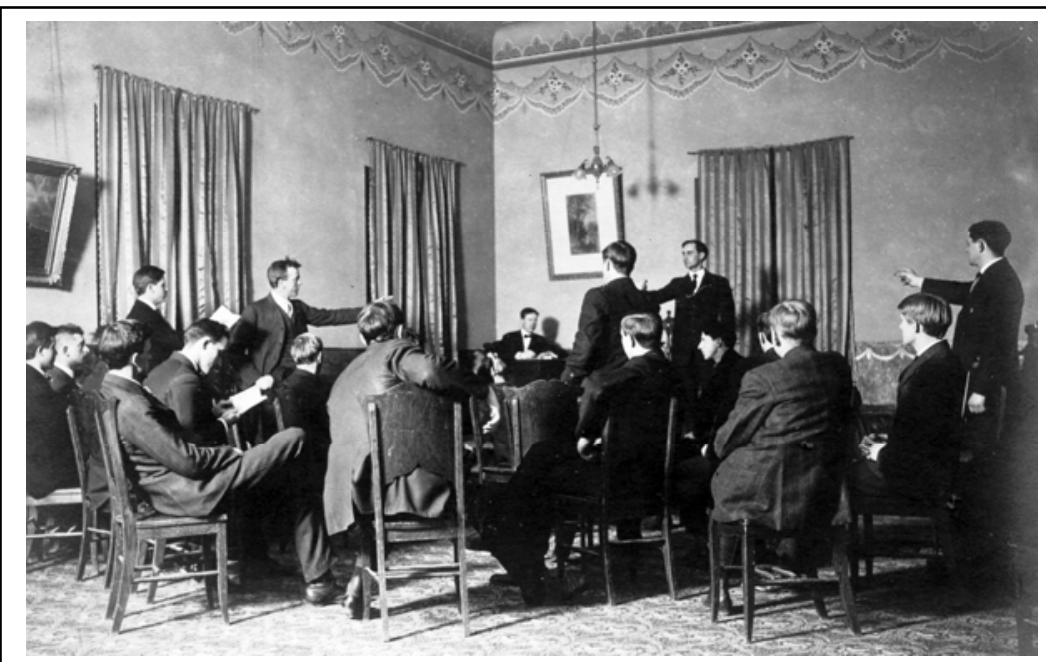

Members of the Miltonian Literary Society at Cornell College engage in a debate in their society hall. At all three institutions, both men's and women's literary society members participated in debates that honed public speaking skills and required awareness of current affairs. Early literary society debates drew large crowds from the community. Later, literary societies organized intercollegiate debates. From Miltonian Records, Literary Society Collection, Cornell College Archives.

pension policy, and the annexation of Hawaii. When Hesperian programs included debates, the women might explore a national political issue, but regularly focused on domestic, educational, or campus issues. The women considered allowing upper classmen to attend the Freshmen Party, the benefits of intercollegiate football, and providing free textbooks, lunches, and baths in public schools. The Hesperian women engaged literary topics more regularly than the Zetagathians. Hesperians wrote poems and short stories that they presented at their programs. In addition to such original pieces, Hep programs highlighted the works of accomplished authors. Each year, Hep women also planned programs that featured seasonal or holiday themes. ${ }^{21}$

21. Hesperian Program Poster Collection, Hesperian Literary Society Papers, UIA; Zetagathian Program Poster Collection, Zetagathian Literary Society Papers, UIA. 
For much of their existence, literary societies commemorated the end of the school year and members' graduation with large public programs attended by commencement visitors. At the end of the first year at Iowa Conference Male and Female Seminary, students participated in three days of well-publicized "exhibition exercises," which included public examinations, orations, and musical performances. As these exhibition exercises evolved into Cornell College's commencement activities, literary societies became responsible for planning "class exercises" during the days before graduation. Fifteen years after the first exhibition exercises, the Amphicytons presented class exercises consisting of two essays, two orations, a speech by a graduating member, six musical performances, and a debate on a looming question for

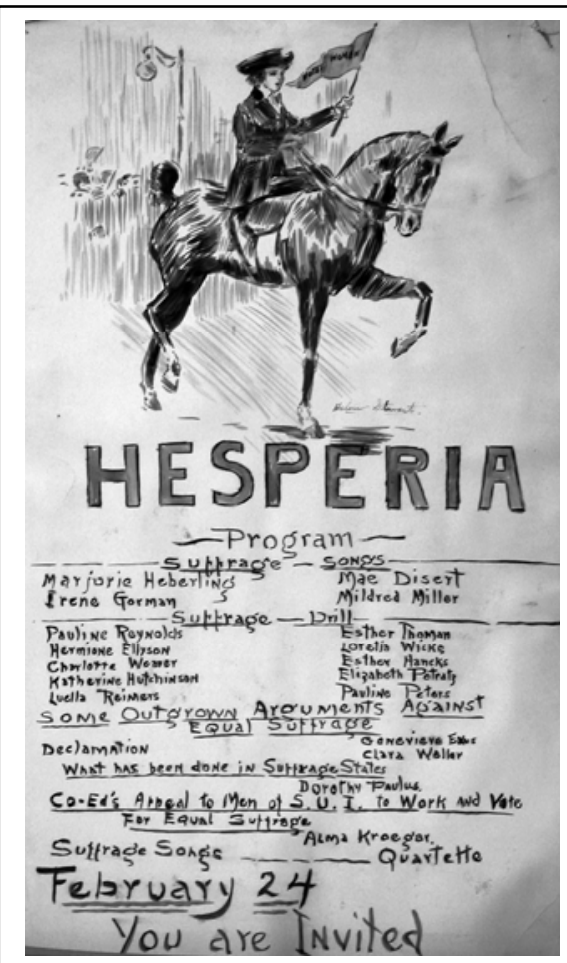

A Hesperian program poster from the 1910s at SUI announces a special suffrage program. The program included suffrage songs, "some outgrown arguments against equal suffrage," and a call to SUI men to support woman suffrage. From Records of the Hesperian Literary Society, Special Collections and University Archives, University of Iowa Libraries.

many graduates: "Do the learned professions offer so great inducement as business pursuits?" SUI's first four literary societies marked the end of each academic year with a joint program called "commencement exercises" beginning in 1869. Representatives from each society demonstrated their speaking skills in front of large crowds, and the societies presented their graduating members with diplomas. ISNS celebrated its twenty-fifth 


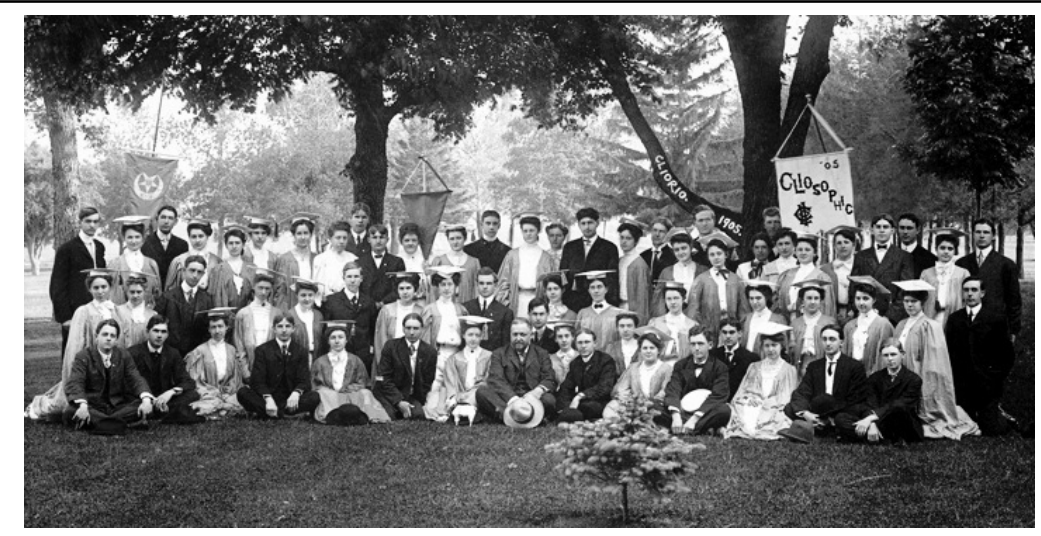

Members of the Cliosophic and Orio literary societies, many wearing mortar boards and graduation gowns, pose for a photograph on commencement day at Iowa State Normal School in 1905. Literary societies planned commencement activities at all three institutions for many years. From University Archives, University of Northern Iowa.

anniversary with a six-day event, estimated to attract 1,500 alumni, culminating with the Class of 1901's graduation. The women's societies began the celebration with a joint program in the afternoon of Friday, June 7. The men's literary societies presented their program the next evening. Alumni provided "literary" entertainment - skills they had developed as society members - the day before commencement. ${ }^{22}$

Literary societies at these Iowa institutions generally eschewed a private activity that was common among the societies at eastern men's colleges: the establishment of society libraries. The Adelphians at Cornell College were the notable exception. By 1862 they had amassed a library of more than 300 books; the collection quadrupled to nearly 1,200 volumes by 1888 . The literary society's library included works of American and English literature and, compared with the slow-growing college library, remained the students' main source of modern reading for many years. Eventually the society's books were donated to the college

22. Heywood, Cornell College, 26-27; "Class Exercises" (1869), Amphicyton Literary Society Papers, CCA; Lavender, "Erodelphian and Hesperian Societies," 43-46; Wanerus, Zetagathian Society, 59-66; "Program for the Quarter Centennial Anniversary of the State Normal School," Normal Eyte, 5/4/1901. 
library, and other societies and their alumni provided additional support, establishing the Star Literary Society Alcove of Psychology and the Adelphian Literary Society Alcove of American History. Yet SUI's Zetagathians' private library was more representative of Iowa societies' efforts to establish libraries, which were unsuccessful if attempted at all. Due to the lack of space for a library in the society hall, the members' lack of time to monitor a library, and the growth of the university library, the Zets auctioned their private library in $1870 .{ }^{23}$ There is no evidence that women's societies created private libraries at any of the three institutions.

Students designed their society programs in large part to display their education to other students and to the larger community. Debates enabled them to demonstrate mastery of an issue and required students to predict which arguments might prove most persuasive with the judges and audience. Through recitations, orations, speeches, essays, and reading original works of poetry and fiction, literary society members presented information they had learned or created. At the end of their higher education, the most accomplished literary society members, both men and women, performed in front of large audiences consisting of their peers, their faculty, their parents, and other commencement visitors. But literary society members did not limit themselves to society programs; these students made many other contributions to campus life. The common denominator among these features of campus life was their place in the public sphere.

AT CORNELL COLLEGE, SUI, and ISNS, student literary societies made significant contributions to their campuses, many of which became institutionalized features of the institution. Most literary society programs included musical performances, providing both student and community musicians with attentive audiences. The literary societies' members' emphasis on music was significant because only at ISNS was music initially included

23. Montgomery and Kerr, "Adelphian Society"; Heywood, Cornell College, 58; "Star Literary Society Alcove of Psychology," Star Literary Society Papers, CCA; Parke E. Simmons to Prof. James E. Harlan, 4/7/1905, Adelphian Literary Society Papers, CCA; Wanerus, Zetagathian Society, 69-73. 
in the curriculum. After the normal department closed at SUI, the university stopped offering music courses to students. Yet the university's literary societies supported music. Erodelphian women added music to their programs beginning in 1863, and musical performances regularly constituted a large portion of society programs. In an effort to attract larger audiences than their rivals, the men's societies spent heavily - sometimes as much as $\$ 20$ per act - on musical performances, before agreeing to limit musical expenses to less than $\$ 2$ per week. As their budgets grew, the societies purchased pianos for their halls. SUI societies also provided performance opportunities for early campus musical groups such as the Law Quartette, the Guitar Club, and the SUI Orchestra. At Cornell College, only "shortterm and part-time" instructors taught music until the establishment of the music conservatory in 1879. Literary societies, however, demonstrated an interest in music for their entire existence. The third anniversary program of the Philomathean Society at Cornell College in 1860 included four musical performances. As late as 1907, the women of the Aesthesian Literary Society traded their typical society program for a musical concert. At ISNS, whose first music faculty member arrived in 1879, students received a more formal musical education in comparison to Cornell or SUI, but there, too, literary society programs featured musical performances. ${ }^{24}$

Literary societies also supported students' theatrical interests long before the institutions' curricula offered opportunities in the dramatic arts. ISNS students found their only dramatic opportunities within literary society productions until the institution hired its first dramatic instructor in 1904. The Philomatheans and Alphas closed the winter term of 1879 with a performance of the two-act play Bread on the Water, and the Shakespearean Circle women presented an abridged version of The Merchant of Venice in 1898. Students were unable to major in theater until 1938 at Cornell College, but literary societies often sponsored dramatic productions. The Alethean women presented the Ger-

24. James Senior Stinehart, "History of the State University of Iowa: Musical Activity to 1915" (master's thesis, State University of Iowa, 1941), 14; Lavender, "Erodelphian and Hesperian Societies," 30-31; Wanerus, Zetagathian Society, 52-53; Lang, A Century of Leadership, 65-67, 69. 


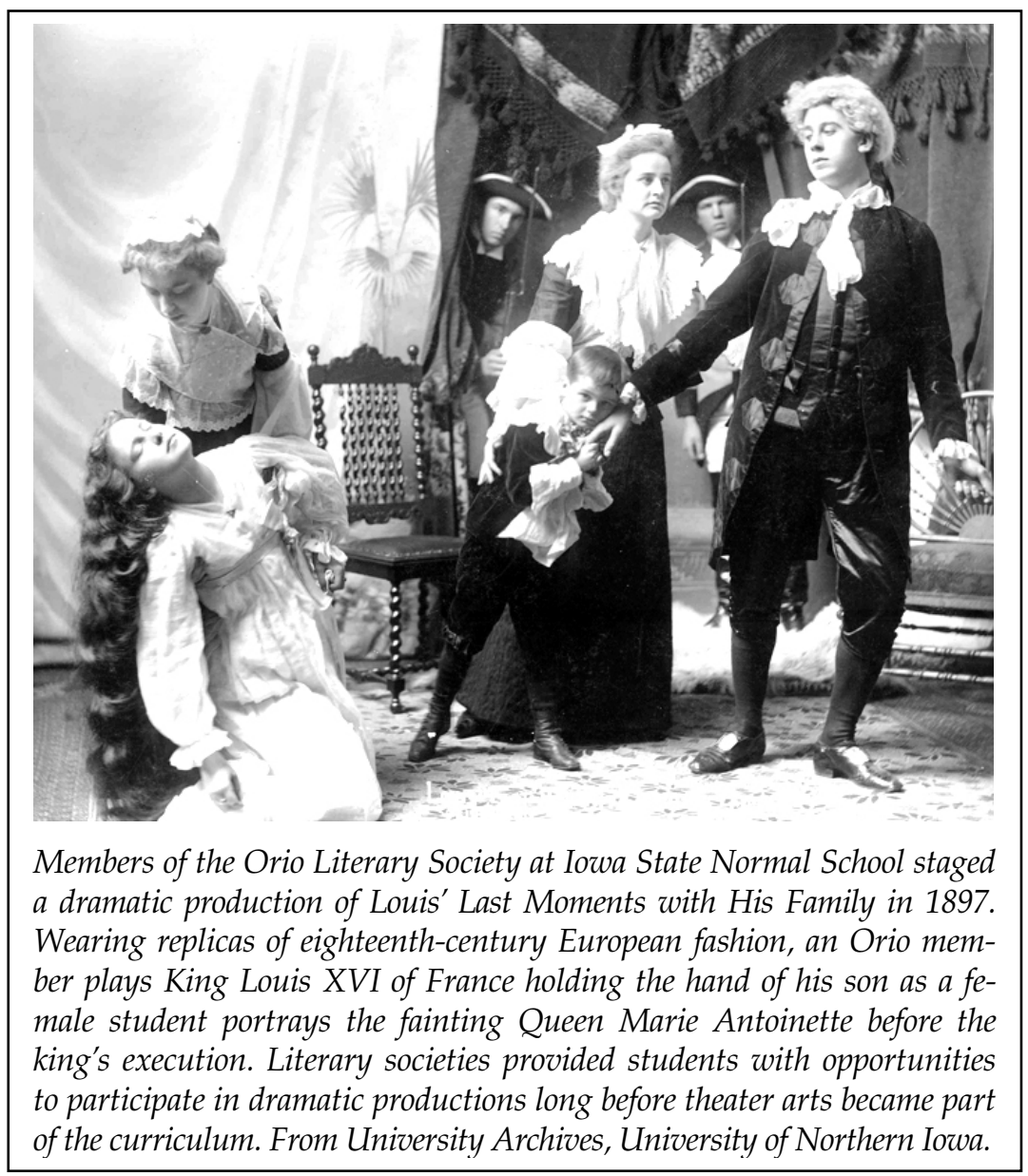

man play, Einer Muss Heiraten (One Must Marry) in 1902; five years later the Aesthesian members performed Shakespeare's A Midsummer Night's Dream; and the Philomathean women teamed with the Adelphian men to stage a five-act comedy in 1914. The literary societies produced their plays independently until 1917, when Professor Clyde Tull joined the Cornell faculty and began improving their dramatic efforts. The first dramatic performance at SUI occurred when the Zetagathians and their "lady friends" presented scenes from The Merchant of Venice and two other plays in 1870. Hesperian members began performing farces in 1888; their initial comedic effort drew an audience that 
approached 600 . That same year marked the first collaborative theatrical venture between two societies when the Erodelphian women and Irving Institute men presented the comedy She Stoops to Conquer. A decade later, the Zetagathian and Hesperian Societies performed In Football Clothes, a farce written by a Zet who was also captain of the football team. The play centered on a Thanksgiving Day football game between the universities of Iowa and Minnesota. In 1901 SUI literary society members helped establish the Dramatic Club, and when the University Theatre was organized 20 years later, the original membership consisted of one drama group and five literary societies. During the University Theatre's first season, men's and women's literary societies paired off to present three of the five performances.

Literary society members were also instrumental in the development of campus newspapers. Dissatisfied with SUI's first campus paper, The University Reporter, the Zetagathians and Hesperians established a new monthly circular, The Vidette, which was published from October 1879 until September 1881, when faculty requests and fiscal shortfalls consolidated the two papers into the Vidette-Reporter. A board of editors, all literary society members, controlled the new paper. Although a school of journalism would form in 1924, remarkably little faculty support guided literary society members when they carried the burden of producing the student newspaper. At Cornell College, literary societies published the campus newspaper for more than 30 years. In 1869 students created the Collegian, which they renamed the Cornellian in 1890. The women of the Alpha Society produced the first campus circular at ISNS. It soon evolved into The Students' Offering, which was printed from 1878 until 1884. In the beginning, the paper's editorial board was selected from the entire student body, but in the last five years the Philomathean and Alpha societies shared responsibility for the publication. In

25. Students' Offering, 5/1/1879; Lang, A Century of Leadership, 202, 456; "Alethean Literary Society German Play" (1902), Alethean Literary Society Papers, CCA; "A Midsummer Night's Dream Presented by the Aesthesian Literary Society" (1907), Aesthesian Literary Society Papers, CCA; Lavender, "Erodelphian and Hesperian Societies," 39-43; Wanerus, Zetagathian Society, 66-68; Elinor F. Jones, "The University Theatre," History of the State University of Iowa, vol. 8, Miscellaneous Papers (Iowa City, 1945), UIA; The 1923 Hawkeye Yearbook (Iowa City, 1922), 307. 
1892, the literary societies provided most of the leadership for the institution's new student paper, The Normal Eyte. ${ }^{26}$

Literary societies invited prominent politicians, social reformers, and authors to speak on campus to the larger student body. At SUI, the Zetagathian Society and the Irving Institute created the SUI Lecture Bureau in 1890 to bring speakers to campus. In its first season the lecture bureau generated a profit of \$1.01 per society. The following year the societies split profits of over \$250. The Lecture Bureau continued through 1902, when a combination of an "unusual number of other entertainments" and "the unhappy coincidence of stormy weather" during the scheduled lecture nights forced the Zets and the Irvings to cover a \$131 deficit, effectively ending the collaborative effort. Although the men's literary societies at SUI formalized an organization to arrange campus lectures, the Erodelphian women secured the most prominent visitor when Jane Addams accepted their invitation to deliver a lecture series in January 1900. At the time of her visit, the 40-year-old Addams had recently completed her first decade leading Chicago's Hull House, where she and her colleagues offered social and educational programs to members of the working class and urban poor. Upon learning of Addams's upcoming visit, Professor George Patrick gave her lectures his "hearty endorsement": "Miss Addams is a charming lecturer and both the charm and the power of her lectures are due to the fact that she knows just what she is talking about, and her knowledge comes not from books nor from theories, but from real experience in social reform work." Addams titled her SUI lecture series "Democracy and Social Ethics" - also the title of a book she published two years later. Her six lectures occurred in the afternoons at the crowded Unity Church in Iowa City. In her first lecture on current social problems, Addams told students and community members that "to fulfill the demands of our social morality and devote ourselves to the good of the whole, we must have some idea of the experiences of the whole."

26. Wanerus, Zetagathian Society, 74-78; Millicent B. Righter, "The History of Journalism at the State University of Iowa, 1868-1924" (master's thesis, University of Iowa, 1950); Carol C. Ouckrop, "A History of the University of Iowa School of Journalism" (master's thesis, University of Iowa, 1965), 12-16; Heywood, Cornell College, 140; Lang, A Century of Leadership, 67-68, 191-92. 
Over the course of the remaining lectures, she asserted that the conditions of the poor were not "universally" their fault, used the example of a truant boy to demonstrate problems in the educational system, and questioned wealthy capitalists who assumed to know the "needs and appreciations" of those intended to benefit from their "great public gifts." At the end of Addams's lectures, the student newspaper editors thanked the Erodelphians for planning such an important visit. ${ }^{27}$

Literary society members instigated early intercollegiate competition by entering into forensic contests with their peers at other institutions and establishing organizations to coordinate such opportunities. Intercollegiate competition among the three institutions began in February 1874, when Frank Brush, representing SUI's Zetagathians, traveled to Knox College in Illinois. Upon arrival, he faced students from seven other institutions in an oratorical contest for a $\$ 100$ first-place prize. Both men and women society members at SUI participated in intercollegiate debates. The first intercollegiate debate involving SUI students occurred in 1893, when a team composed of two Zets and one Irving member ventured north to Minneapolis. There, SUI men defeated a team from the University of Minnesota over the issue of government ownership of the telegraph system. Three years later, Erodelphian and Hesperian women combined efforts to challenge University of Wisconsin women to a debate. The University of Wisconsin's president responded that public debate was inappropriate for women, writing, "While there are occasions when women are called upon to discuss questions of a more or less public interest, they are so few in number and occur so infrequently that it was not at Madison thought best to encourage a movement of this kind." Not long deterred by this rebuke, the Hesperians accepted an invitation to debate from Cornell College's Philomatheans and traveled to Mount Vernon in 1899; the next year the Hesperians invited the Philomatheans to Iowa City for a debate. ISNS men first experienced intercolle-

27. Wanerus, Zetagathian Society, 97-104; The Vidette-Reporter (Iowa City), 12/9/ 1899, 12/16/1899, 1/13/1900, 1/25/1900, 1/27/1900; Jane Addams, Democracy and Social Ethics (New York, 1902). For an early controversy involving a speaker the Adelphians invited to campus in the 1860s, see Heywood, Cornell College, 57. 
giate debate in 1894 against Iowa Agricultural College (now Iowa State University). Twenty-four students traveled from Ames to Cedar Falls to witness the ISNS students win the debate. Cornell College's president and faculty began encouraging male students to engage in intercollegiate debates in $1896 .{ }^{28}$

In an effort to have more regular and equitable intercollegiate opportunities, literary society members collaborated with the faculty to establish formal organizations responsible for planning those contests. At ISNS, male and female literary society members formed the Oratorical Association in 1893. The Iowa State Oratorical Association, comprising colleges and universities across the state, prohibited normal school students from competition because their institution did not offer a fouryear collegiate course of study. Two years later, the Inter-State League of Normal Schools formed to promote oratorical contests for normal school students, and ISNS students eagerly participated. In January 1898, the men's literary societies established the Debate League to arrange intercollegiate debates. Female students, mostly literary society members, created the Women's Debate League for a similar purpose in 1913. Five years earlier at SUI, faculty and male society members formed the Forensic League to plan and prepare for intercollegiate debate and oratorical contests. All men's literary societies belonged to the league, and the Forensic Council, made up of five faculty members and four men's society members, controlled the league. Women's literary society members led the effort to create a similar organization, which resulted in the Women's Forensic Council in 1913. Women elected three faculty representatives to serve alongside a woman from each society. Around the turn of the twentieth century, the men of the Adelphian, Amphicyton, Miltonian, and Star societies formed the Debating League of Cornell College. Cornell College women also engaged in intercollegiate debates, but there is no evidence that they created a formal organization to arrange such opportunities. ${ }^{29}$

28. Wanerus, Zetagathian Society, 121-24; Lavender, "Erodelphian and Hesperian Societies," 53; Lang, A Century of Leadership, 194-96, 451-53; Normal Eyte, 2/22/1896.

29. Lang, A Century of Leadership, 194-96, 451-53; Normal Eyte, 1/29/1898; "Women's Debating League is Organized," College Eye, 9/24/1913; Wanerus, 


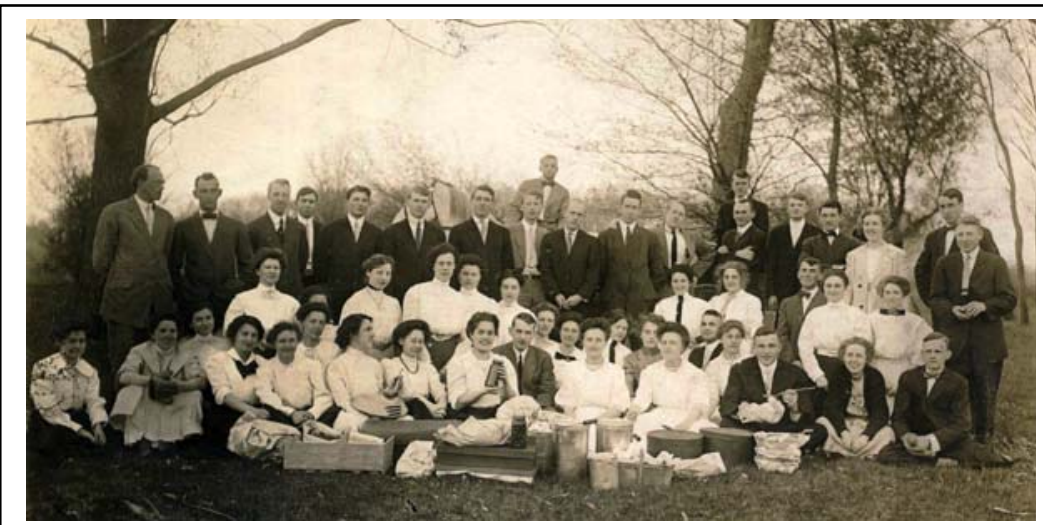

Members of men's and women's literary societies at Cornell College enjoy a picnic at Palisades Park along the Cedar River. Literary society events offered students socially acceptable opportunities to interact with the opposite sex at each institution. Such opportunities were especially important when campus rules prohibited unsupervised interactions between the sexes. From Literary Society Collection, Cornell College Archives.

Literary societies at these three Iowa institutions provided students with many opportunities, but the one perhaps most treasured by students was a socially acceptable means to interact with members of the opposite sex. Each institution admitted both men and women from its opening, but coeducation, particularly during the institutions' earliest years, was a source of great angst for faculty members charged with monitoring student behavior. That anxiety resulted in strict rules limiting the interaction between male and female students. Nowhere were the rules stricter than at Methodist-supported Cornell College, which prohibited students of the opposite sex from walking together; a faculty member even reprimanded a male student for helping a female student who had tripped. However, society programs at Cornell College ended with a "sociable" in which society members informally visited with those in attendance. At ISNS, the Philomathean men and Alpha women began joint programs in the fall of 1877. Faculty members soon created a

Zetagathian Society, 144-47, 177-79; Lavender, "Erodelphian and Hesperian Societies," 61; "Constitution of the Debating League of Cornell College," Debating League Papers, CCA. 
rule that required societies to gain their permission in advance for joint programs. Students often secured faculty support and used the guise of society work to interact with the opposite sex. Campus regulations permitted male and female students to "mingle in groups but not in pairs." An early alumna recalled that when faculty members discovered a couple alone but in "earnest conversation," the students "would be absolved from discipline when they asserted that their detention was due to the complications arising in making out the next program for a joint meeting of the literary societies, and perhaps be commended for being engaged in so laudable pursuit, although no visible signs of their work might be apparent." At the turn of the twentieth century at SUI, male students often asked female students to attend society programs as their dates. For parties, Zets often drew names of Hep members to ensure that every woman had an escort. Through their involvement in a literary society, women occasionally were responsible for asking men to attend functions. Ione Mulnix, a Hesperian from 1904 to 1909, drew the names of two Zet "freshies" to bring to a leap year party her junior year. A month later, the women were to ask men to attend an intersociety debate. ${ }^{30}$

The students who joined and supported literary societies made many contributions to their campuses outside of their formal programs. Those contributions, like their programs, offered students opportunities to publicly demonstrate the learning and culture associated with their higher education. Students who performed musically or theatrically displayed their talents to an audience comprising fellow students as well as the larger community. Students who controlled and wrote for the campus newspaper offered their writings and opinions for public consumption and critique. Intercollegiate debates and other forensic competitions attracted the public's attention to a degree typically associated with athletics. And faculty members and administrators were amenable to men and women students

30. Heywood, Cornell College, 139-40; Lang, A Century of Leadership, 66; Ione Mulnix to Parents, 1/29/1908, 3/9/1908, Ione Mulnix Papers, Iowa Women's Archives, University of Iowa Libraries, Iowa City. Andrea Radke-Moss, Bright Epoch, 110-11, finds literary societies performing a similar role at land-grant colleges. 
interacting through literary society events because they considered these activities to occur in public space. The public nature of literary societies placed them in stark contrast to the inwardly directed fraternities and sororities that slowly developed at each institution.

HISTORIANS often place much of the blame for the demise of student literary societies on college fraternities, which developed at eastern colleges several decades after literary societies, arguing that students developed a stronger loyalty to these smaller, selective, and secret organizations than to the more egalitarian and inclusive literary societies. ${ }^{31}$ However, an examination of the relationship between these organizations at Cornell College, ISNS, and SUI suggests that the decline of literary societies was more complicated. Moreover, inserting women's organizations into the student literary society narrative requires a consideration of the relationship between women's literary societies and sororities. Fraternities and sororities developed differently on each campus, and the relationship between these organizations and literary societies varied among and within the campuses.

Of all the literary societies at these institutions, the contested role of fraternity members in the Zetagathian Literary Society at SUI most closely resembles the traditional historical narrative. Some Zetagathians became charter members of the university's early fraternities, but a rift eventually developed within the society between fraternity men and nonfraternity members, caused primarily by fraternity men electing only themselves to the Zets' "various positions of honor." In April 1887 tensions escalated as the Zets considered an amendment to the society's constitution that would prohibit fraternity men from society membership. In "one of the hardest parliamentary battles ever fought in Old South Hall," 51 members debated the role of fraternity men within the literary society. By a vote of 37 to 14, the Zets adopted the amendment with three more votes than the two-thirds majority required. Even after the ban, the admittance of fraternity members into the society continued to be an issue for the Zets.

31. Rudolph, The American College, 146; Horowitz, Campus Life, 29. 


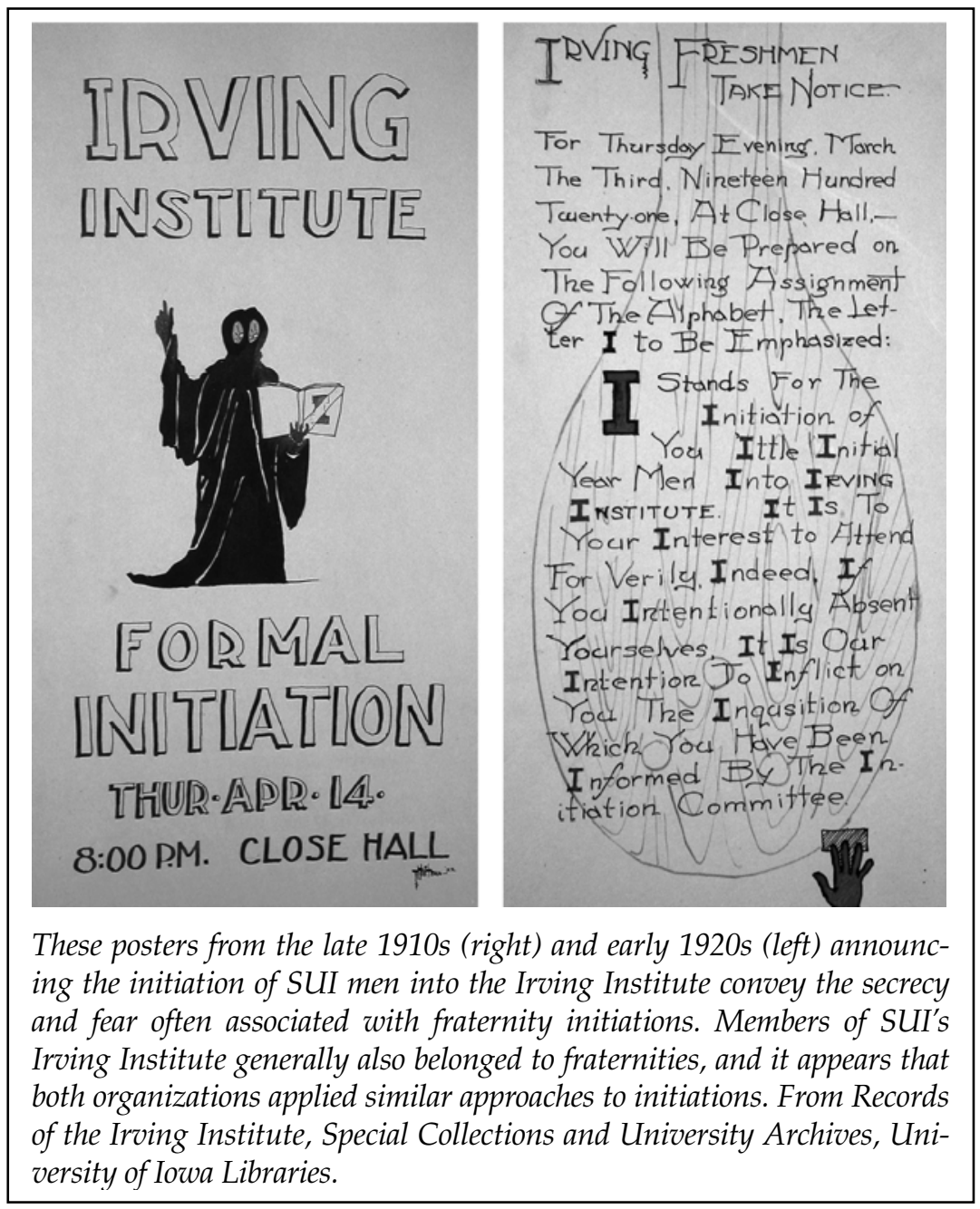

Some Zets regularly presented proposals to remove the constitutional ban on fraternity membership. In 1902 the society lost the best student orator at SUI when he joined a fraternity. By 1905 the Zets had changed their mind regarding the compatibility of fraternity and literary society membership. This "longest and hardest fought controversy" of the Zetagathian Society had come to an end, leading the society's historian to conclude that rivalry between the two types of organization no longer existed 
and that "the two now flourish side by side, neither encroaching upon the rights of the other." ${ }^{32}$

Although the Zets struggled with the role of fraternity men in their organization for two decades, the more prevalent relationship between literary societies and fraternities and sororities at SUI was one of peaceful coexistence. Literary societies existed as the sole extracurricular outlet for only four years at SUI. Men had formed two fraternities by 1867, and five fraternities and two sororities were actively recruiting members by 1882. Fraternities and sororities at SUI encouraged their members to belong to literary societies. In the 1891 Hawkeye yearbook, Pi Beta Phi sorority women noted that their requirements for membership included literary society involvement. That same year almost a quarter of Irving Institute men also belonged to a fraternity. Sororities likely extended the life of women's literary societies. Awarding "points" to those who joined literary societies, sorority women made up the majority of society members during the societies' waning years. ${ }^{33}$

In comparison to SUI, literary societies and secret societies were more directly connected at Cornell College. There, the board of trustees, presidents, and faculty members worried over the private nature of fraternities and sororities and never permitted students to establish such organizations. The prohibition, however, did not stop students from creating and joining such organizations. Cornell's first secret society developed shortly after the institution opened. The "Literary Klub" shared characteristics of both a literary society and a fraternity. Limited to 12 secret male members, students designed their meetings to improve their writing and debating skills. The same early alumnus who recalled the Amphicytons scaling Main Hall to claim their society room remembered the Klub as an "aristocratic society, composed of only a few students, who did not care to make

32. Wanerus, Zetagathian Society, 105-20; R. C. Craven, V. F. Price, W. S. Anderson, W. H. Dart, N. DuPuis, A. N. Naven, and Rich. G. Hargrave to Zetagathian Society, 4/23/1887, Zetagathian Literary Society Papers, UIA.

33. Wanerus, Zetagathian Society, 107-8; Bette Towner, "Sororities at Iowa," in The History of the State University of Iowa, vol. 1, Miscellaneous Papers (Iowa City, 1944), UIA; "Irving Institute" and "Pi Beta Phi" in The Hawkeye Junior Annual of the Class of '92 (Iowa City, 1891); Lavender, "Erodelphian and Hesperian Societies," 117. 
known their number, but felt so self-centered that no one could get into their number save just such as they were sure they wanted." The Klub did not last long, and it appears that Cornell students did not form another secret society until the turn of the century. Although faculty-approved literary society constitutions forbade society members from joining fraternities or sororities, some students used their literary societies to conceal secret societies. Edith Dayton, a member of the Aesthesian Literary Society who graduated in 1907, received an invitation to become initiated into a sorority apparently sponsored by her literary society. "This is very secret owing to the disfavor which sororities have at Cornell," explained the sorority's corresponding secretary. In May 1923 several members of the Adelphian Literary Society "were taken into" the Delta New Hand Fraternity, likely joining older Adelphian members who had previously been initiated. ${ }^{34}$

When Herbert Burgstahler assumed the presidency of Cornell in 1927, he confronted the "long-standing problem" of the existence of prohibited fraternities and sororities on campus. There were at least ten secret societies, and students became bolder in their public displays of their unapproved fraternal membership. After the recommendations regarding fraternities and sororities on campus from a committee of students and faculty failed to create consensus among the larger faculty, one faculty member organized a class to explore the issue. A survey conducted by the class revealed that over half of Cornell students belonged to fraternities or sororities. The class's efforts resulted in a compromise, rejecting the existence of "fraternities" and "sororities" but permitting the creation of "social groups" that shared characteristics with secret societies. The faculty required that these organizations be "democratic" in nature and not affiliate with national fraternities and sororities. The social groups were also not to name themselves with Greek letters or with the words "fraternity" or "sorority" (the social groups generally ignored the prohibition of Greek letters in their names). In many ways - including their single-sex nature, smaller number of members, emphasis on social activities, and adoption of

34. Foster, "Early Recollections," 11-12, CCA; Heywood, Cornell College, 59; Beulah Perren to Edith Dayton, n.d., Aesthesian Literary Society Papers, CCA; The Cat's Meow (Mount Vernon), 5/12/1923, CCA. 
Greek letter names - these social groups resembled "local" fraternities and sororities found on other campuses. ${ }^{35}$

Among the three institutions, students waited the longest to form fraternities and sororities at ISNS. As at Cornell College, long-standing regulations, passed by the Board of Directors two months before the institution opened, prohibited students from creating and belonging to "secret societies." Students apparently obeyed this rule for 20 years. Women formed the first secret society, $\mathrm{Nu}$ Omicron $\mathrm{Nu}$, in 1896. Three years later, men established the Able Hobo society, limiting it to 13 secret members. The fraternity met in secret locations, both to maintain the anonymity of its membership and because of faculty and student opposition. Men formed the Xanthos Social Club in 1900, replacing "social club" with "fraternity" in the organization's name by 1902. A third fraternity appeared in 1915, by which time women students, who far outnumbered men on campus, had created six sororities, all before any rules permitted them to do so. ${ }^{36}$

In contrast to the varied interests of literary societies, fraternities and sororities at ISNS focused on private matters, especially providing social opportunities to facilitate interaction between male and female students on an intimate scale. For example, $\mathrm{Nu}$ Omicron $\mathrm{Nu}$ women "gave a novel party to their gentlemen friends" on April Fools' Day in 1904. The women planned "progressive games" for the men, blindfolded them and led them around campus into "obstructions" and mud puddles, staged potato races and whistling contests, and served the men "a dainty course luncheon." In February 1907, 15 Able Hoboes and "their lady friends" celebrated the fraternity's "mid-winter banquet" at the Irving Hotel in Waterloo. After arriving "in two sleighs each drawn by four horses," they enjoyed an elaborate meal, which included oyster cocktail, baked red snapper, larded tenderloin of beef, shrimp in mayonnaise, and Neapolitan ice cream, "served by the efficient Irving hotel waiters." Even though the banquet took place on a Wednesday night, the stu-

35. Heywood, Cornell College, 193, 198-201; Alpha Sigma Pi Papers, CCA.

36. Lang, A Century of Leadership and Service, 478-79. 
dents did not return to Cedar Falls until "an early hour in the morning.." ${ }^{37}$

Faculty members at the by then named Iowa State Teachers College failed to take decisive action regarding fraternities and sororities, passing the issue between committees over the course of several years. In September 1914 the Men's Council, a student government group, claimed that such organizations were detrimental to both their members and the entire student body and asked the faculty to prohibit fraternity members from representing the institution in intercollegiate activities or other public performances. The faculty members referred the proposal to a committee that reported to the dean of women but never again addressed the proposal. The following March, the dean of women asked the faculty to support her policy of denying all requests by outside organizations to form secret societies on campus, but President Homer Seerley, the institution's longserving president who himself had belonged to both a literary society and a fraternity at SUI, intervened. He appointed a faculty committee to consider the dean's proposal and make a recommendation to the larger faculty. One year later, President Seerley created another faculty committee to consider the appropriate stance toward fraternities and sororities. The committee, minus one vocal dissenter who proposed penalties for the organizations and their student members, concluded that although fraternities and sororities were of questionable worth, they had developed to such a degree that any attempt to eliminate them would fail. The committee recommended that the faculty begin oversight of the organizations and that each organization be assigned a "sponsor" who would ensure that the members obeyed the rules of the institution. Faculty members debated the committee's proposal before eventually referring the report back to the committee, where apparently the faculty's consideration of fraternities and sororities died. ${ }^{38}$

Regardless of debates in faculty meetings, fraternities and sororities continued to exist as unrecognized groups for another

37. Normal Eyte, 4/9/1904; ibid., 9/24/1904; ibid., 11/9/1904; ibid., 2/6/1907; ibid., 2/12/1908; ibid., 12/7/1910; College Eye, 3/19/1919; ibid., 4/16/1919; ibid., 2/7/1923.

38. Lang, A Century of Leadership and Service, 480-81. 
decade in Cedar Falls. Eventually, most students agreed that fraternities and sororities should be recognized and encouraged to affiliate with national organizations. When campus newspaper editors asked students their opinion of fraternities and sororities on campus in 1925, non-fraternity men replied that the existence of national organizations would be preferable. The editors encouraged faculty oversight. Noting that fraternities and sororities "seem to have flourished in spite of their lack of recognition," the editors argued that the organizations might "do as much for the school as any other organization" if "their steps are led in the right direction." Sorority women and fraternity men concluded that governing councils might encourage faculty recognition. Sorority women formed the Inter-Sorority Council in 1922; fraternity men established the Pan-Hellenic Council the next year. Those early efforts were unsuccessful because administrators and faculty failed to help students enforce their rules. Eventually, fraternity men convinced the faculty of the need for greater oversight. When the Interfraternity Council's new constitution went into effect in the fall of 1926, the voting members of the governing organization consisted of two representatives from each of the campus's three fraternities, two elected faculty members, and the dean of men. ${ }^{39}$

Students established different types of fraternal organizations at the three institutions: at SUI, local chapters of national fraternities and sororities; at Cornell College, "social groups" that shared similarities with secret societies; and at Iowa State Teachers College, local fraternities and sororities. The relationships between literary societies and fraternities and sororities were complex and different at each institution, but fraternities and sororities were not the primary cause of the demise of literary societies at these Iowa campuses. Indeed, literary societies thrived in the public sphere while fraternities and sororities placed their emphasis in the private. The institutionalization of many features of campus life that earlier had been the responsi-

39. "What Do You Think of the Fraternities and Sororities on the Hill?" College Eye, 2/4/1925; "Should Sororities and Fraternities Be Recognized?" ibid., 1/30/1924; Lang, A Century of Leadership and Service, 483; "New Interfrat Council to Begin Work on Big Program this Fall," College Eye, 7/9/1926. 
bility of literary societies and students' shifting interests eventually made the campuses' earliest student organizations obsolete. ${ }^{40}$

THE ZETS had much to celebrate at their anniversary dinner in 1911, yet the alumnis" "note of sadness . . . at the changed position of literary societies" was well warranted. Literary societies at all three institutions struggled to find their niche on growing campuses with more curricular and extracurricular options. By the 1920s, intercollegiate athletic teams, student organizations focused on academic disciplines, curricular opportunities for musical and dramatic performances, and fraternities and sororities competed with literary societies for undergraduates' attention.

Literary societies attempted to adapt to modern times. In the 1920s women's literary societies at SUI began offering radio programs. In 1929 the Erodelphians planned a radio program that included a history of the society, popular songs, poetry readings, and a violin solo. These radio programs also connected the society with their alumnae members. An alumna of the Hamlin Garland Literary Society who had moved to Chicago wrote to the active members after she was unable to listen to the society's radio program: "I didn't forget your broadcasting on the nineteenth for the first thing I did at eight-thirty that Tuesday evening was to turn the dials to WSUI. But I'm very sorry to say that I couldn't reach you as WIBO - a Chicago station - was broadcasting a program at the same time and they have the same wave length. . . . I was very disappointed, needless to say, that I was forced to give up this program of Hamlin

40. Nicholas L. Syrett, The Company He Keeps: A History of White College Fraternities (Chapel Hill, NC, 2009), 135, reaches a similar conclusion: "The story of [the demise of] literary societies is as much the story of the changing interests of post-bellum college students as it is of fraternities' destruction of what had once been a thriving college institution." I generally agree with Syrett's nuanced argument about the role of fraternities in the demise of literary societies, although I disagree with the claim that students' interests (at least at these Iowa institutions) in "theater, music and publication . . . diverted students away from literary societies." Rather, when faculty members and academic leaders institutionalized these features into the curriculum, they simultaneously weakened the position of the literary societies. Dorothy E. Finnegan, "A Potent Influence: The YMCA and YWCA at Penn College, 1882-1920s," Annals of Iowa 65 (2006), 1-34, comes to a similar conclusion regarding the demise of the long-functioning YMCA and YWCA at Penn College in Iowa. 
Garland but am looking forward to more luck the next time." These radio programs proved to be some of the last literary society activities societies at SUI. ${ }^{41}$

Despite efforts to remain relevant, each institution's literary societies were extinct by the mid-1930s. Students' curricular and extracurricular options and interests had widened beyond the multipurpose literary societies. When faculty officially permitted Cornell College students to form social groups in 1928, literary societies disappeared. In December 1927 the Philomathean Society at SUI reorganized as "a literary discussion group," and its final photo appeared in the 1928 yearbook. The final picture of the Irving Institute appeared in the 1929 Hawkeye and that of the Zetagathians in 1933. Most of SUI's women's literary societies' last active year on campus was also 1933. In April 1934 Hamlin Garland, the 74-year-old author who would publish the collection of poems Iowa, O Iowa! the next year, gave a lecture on campus. After the lecture, he dined with members of the university's last active literary society, the organization that bore his name. That banquet appears to be the last recorded activity of a literary society at SUI. Literary societies remained active slightly longer at Iowa State Teachers College. As late as 1920, nearly half of the students belonged to one of the literary societies; a decade later fewer than 20 percent of the students were members. The two oldest men's societies, the Philomatheans and Aristotelians, merged in 1929 to form the Men's Forum, which lasted a few years. Between 1930 and 1935 ten literary societies became defunct. The Shakespearean Circle, the last literary society to exist with official university recognition, remained active until 1937. ${ }^{22}$

The purposes and activities of the literary societies outlived the organizations. The intellectual development and public speaking skills that literary societies fostered were now cultivated in large academic departments and institutionally spon-

41. Lavender, "Erodelphian and Hesperian Societies," 30; Marjorie P. Hansen to Hamlin Garland Society, 4/15/1929, Hamlin Garland Society Papers, UIA.

42. Philomathean Secretary Book 1924-27, 12/9/1927, Philomathean Society Papers, UIA; "Hamlin Garland Will Give Round Table Lecture Here," Daily Iowan (Iowa City), 4/22/1934; Hamlin Garland, Iowa, O Iowa! (Iowa City, 1935); "Hamlin Garland Will Talk at Old Capitol This Afternoon," ibid., 4/25/ 1934. 


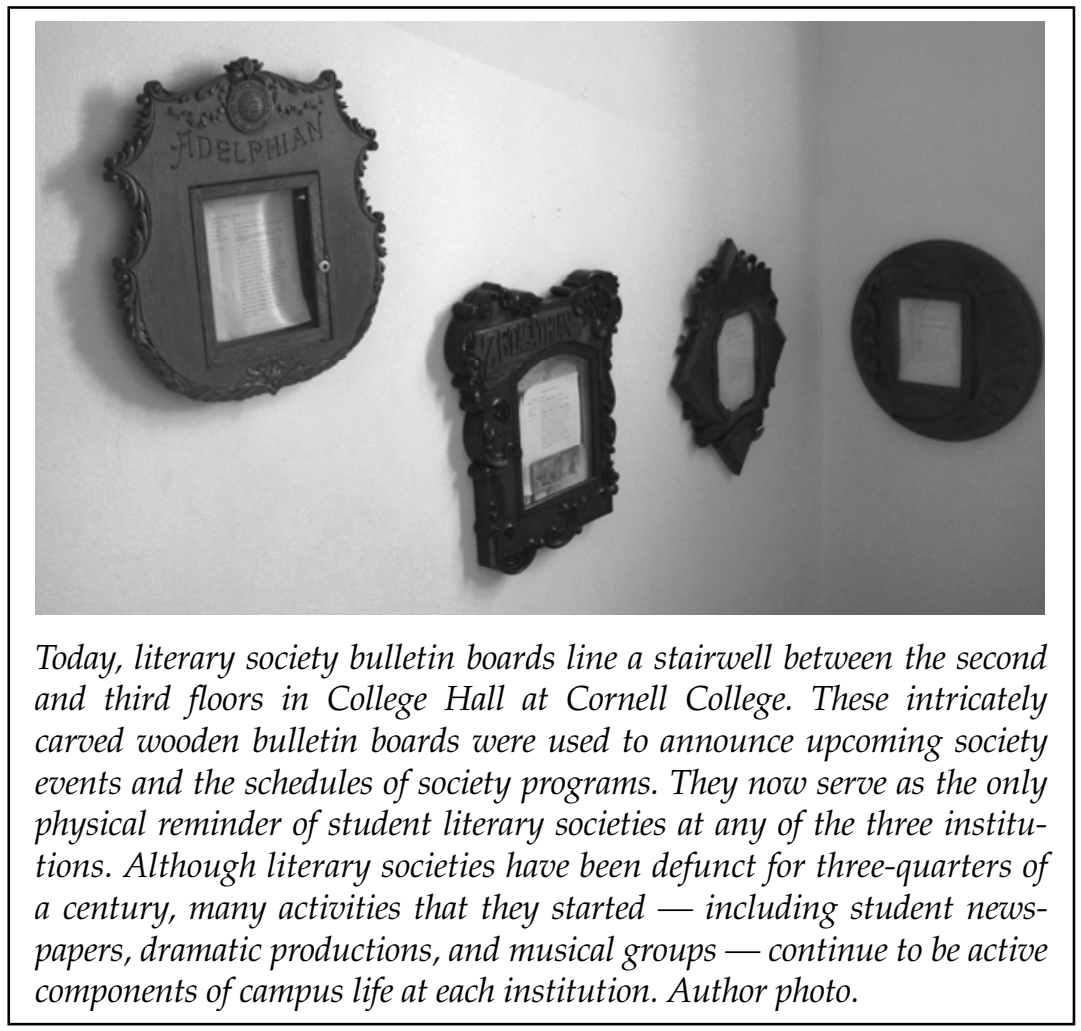

sored forensics and debate programs; the intercollegiate athletic contests and entertainment for the community that literary societies provided were replaced by institutionally sponsored musical and dramatic performances, motion pictures, and radio; the social opportunities that literary societies offered for students were now taken up by fraternities and sororities and many other campus organizations. Each new extracurricular activity weakened the multipurpose literary societies. Perhaps more significantly, many literary society activities became institutionalized in the formal curriculum. Although these Iowa literary societies have been absent from their campuses for nearly threequarters of a century, their formative roles in the lives of the early students and their contributions to their institutions particularly their role in providing students opportunities to publicly display their higher education - deserve to be as well remembered as the literary societies at eastern men's colleges. 